\title{
Double-Strand Break Repair Protein MRE11A
}

National Cancer Institute

\section{Source}

National Cancer Institute. Double-Strand Break Repair Protein MRE11A. NCI Thesaurus. Code $C 98169$.

Double-strand break repair protein MRE11A (708 aa, $81 \mathrm{kDa}$ ) is encoded by the human MRE11 gene. This protein plays a role in the mediation of DNA double-strand break repair, recombination and telomere maintenance. 